JOURNAL OF LATIN AMERICAN STUDIES 1974 


\section{JOURNAL OF}

LATIN AMERICAN

STUDIES

VOLUME $6 \quad 1974$

Editors:

HAROLD BLAKEMORE

CLIFFORD T. SMITH

Editorial Board:
A. R. M. CA R R
P. FLYNN
R. A. HUM PHREYS
J. L Y NCH
J. S T R E E T

C A M B R I D E

AT THE UNIVERSITY PRESS

1974 
Published by the Syndics of the Cambridge University Press

Bentley House, 200 Euston Road, London, NW1 2DB

American Branch: 32 East 57th Street, New York, N.Y. 10022

(C) Cambridge University Press 1974

Printed in Great Britain by The Eastern Press Lid., London and Reading 


\section{Articles}

ARCHER, Christon I.: Pardos, Indians, and the Army of New Spain : Inter-Relationships and Conflicts, 1780-1810

BADER, Thomas M.: Before the Gold Fleets: Trade and Relations between Chile and Australia, 1830-1 848

BROWNING, David: The Rise and Fall of the Central American Common Market

DENT, David W.: Oligarchy and Power Structure in Urban Colombia : the Case of Cali

FLYNN, Peter : Brazil : Authoritarianism and Class Control

FRANCIS, Michael J.: The United States at Rio, 1942: the Strains of Pan-Americanism

FRANKMAN, Myron J.: Sectoral Policy Preferences of the Peruvian Government, I946-I968

GOODWIN, Paul B., Jr.: The Politics of Rate-making: the Britishowned Railways and the Unión Cívica Radical, 1921-1928

HOBERMAN, Louisa: Bureaucracy and Disaster: Mexico City and the Flood of 1629

MITCHELL, Simon: The Influence of Kinship in the Social Organisation of North East Brazilian Fishermen: A Contrast in CaseStudies

PEREZ, Louis A., Jr. : Army Politics, Diplomacy and the Collapse of the Cuban Officer Corps: the 'Sergeants Revolt' of 1933

POOLE, B. T. F.: Case Reopened: An Enquiry into the 'Defection' of Fray Bernal Boyl and Mosén Pedro Margarit

ROBINSON, David J. and THOMAS Teresa: New Towns in Eighteenth Century Northwest Argentine

SCHMIDT, Steffen W.: La Violencia Revisited: the Clientelist Bases of Political Violence in Colombia

WINN, Peter and KAY, Cristobal : Agrarian Reform and Rural Revolution in Allende's Chile 


\section{Reviews}

Alden, Dauril (ed.): Colonial Roots of Modern Brazil, by A. J. R. Russell-Wood

Ampuero, Raúl D.: La izquierda en punto muerto, by Simon Collier

Angell, Alan: Politics and the Labour Movement in Chile, by Torcuato S. di Tella

Arnove, Robert F.: Student Alienation: A Venezuelan Study, by D. Winder

Bonilla, Frank: The Failure of Elites, by John Stuart Macdonald

Brundage, Burr Cartwright: A Rain of Darts: The Mexico Aztecs, by Warwick Bray

Burggraaff, Winfield J.: The Venezuelan Armed Forces in Politics, 1935-1959, by George E. Carl

Burns, E. Bradford: A History of Brazil, by Peter Flynn

Churchill, Anthony, et al.: Road User Charges in Central America, by Kenneth Duncan

Cuissoun, Stephen: Latin America, New World, Third World, by F. Parkinson

Conen, David W. and Green, Jack P. (eds.): Neither Slave Nor Free. The Freedmen of African Descent in the Slave Societies of the New World, by D. R. Murray

Conrad, Robert: The Destruction of Brazilian Slavery, $1850-1888$, by D. R. Murray

DE Kadr, Emanuel (ed.): Patterns of Foreign Influence in the Caribbean, by D. A. G. Waddell

Denton, Charles F.: Patterns of Costa Rican Politics, by Peter Calvert

Díaz-Alejandro, Carlos F.: Essays on the Economic History of the Argentine Republic, by Markos Mamalakis

Griffiths, B.: Mexican Monetary Policy and Economic Development, by Miguel S. Wionczek

International Bank for Reconstruction and Development. Avromic, D. (ed.): Economic Growth of Colombia: Problems and Prospects, by Alan Gilbert

Keen, Benjamin: The Aztec Image in Western Thought, by C. A. Burland

King, Richard G., with Rangel Guerra, Alfonso, Kline, David and McGinn, Noel: The Provincial Universities of Mexico: An Analysis of Growth and Development, by D. Winder

KirkPatrick, Jeanne: Leader and Vanguard in Mass Society: A Study of Peronist Argentina, by R. D. Moseley-Williams 
Lechner, Norbert: La democracia en Chile, by Simon Collier

Lockart, James: The Men of Cajamarca. A Social and Biographical Study of the First Conquerors of Peru, by John Fisher

Love, Joseph L.: Rio Grande do Sul and Brazilian Regionalism I882-1930, by Peter Flynn

Lowenthal, David: West Indian Societies, by J. S. Macdonald

McClelland, Donald H.: The Central American Common Market, by David Browning

I6I

Mattelart, Armand, Castillo, Carmen and Castillo, Leonardo: La ideologia de la dominación en una sociedad dependiente, by Simon Collier

Maullin, Richard: Soldiers, Guerrillas and Politics in Colombia, by Christopher Abel

Meyer, Michael C.: Huerta, a political portrait, by Peter Calvert

Odell, P. R. and Preston, D. A.: Economies and Societies in Latin America: a Geographical Interpretation, by David J. Fox

Orantes, Isaac C.: Regional Integration in Central America, by David Browning

Quartim, João: Dictatorship and Armed Struggle in Brazil, by Peter Flynn

Roetr, Riordan : Brazil; Politics in a Patrimonial Society, by Peter Calvert

Roetr, Riordan (ed.): Brazil in the Sixties, by Peter Flynn

Roetr, Riordan: The Politics of Foreign Aid in the Brazilian Northeast, by J. T. Winpenny

Rosenbaum, H. Jon and Tyler, W. G. (eds.): Contemporary Brazil: Issues in Economic and Political Development, by Peter Flynn

SAunders, John (ed.): Modern Brazil. New Patterns and Development, by Peter Flynn

Schmitter, Philippe C. (ed.): Military Rule in Latin America: Function, Consequences and Perspectives, by James D. Cochrane

Schmitter, Philippe C.: Interest, Conflict and Political Change in Brazil, by Peter Flynn

Schneider, Ronald M.: The Political System of Brazil: Emergence of a Modernizing Authoritarian Regime, 1964-1970, by Peter Flynn

Sharp, Daniel A.: U.S. Foreign Policy and Peru, by Bryce Wood

Silva Michelena, José A.: The Illusion of Democracy in Dependent Nations, by John Stuart Macdonald

Smith, T. Lynn: Brazil, People and Institutions, by J. P. Dickenson

SNow, Peter G., Political Forces in Argentine, by Peter Calvert

Solaún, Mauricio and Quinn, Michael A.: Sinners and Heretics: The Politics of Military Intervention in Latin America, by James D. Cochrane

Stedman, Captain J. G.: van Lier, R. A. J. (ed.): Narrative of a Five Years' Expedition against the Revolted Negroes of Surinam in Guiana on the Wild Coast of South America from the Years 1772 to 1777 , by Sister Mary Noel Menezes 
Toplin, Robert Brent: The Abolition of Slavery in Brazil, by D. R. Murray

Vallier, Ivan: Catholicism, Social Control, and Modernisation in Latin America, by Peter Flynn $\quad 316$

von LAzAr, Arpad: Latin American Politics: a primer, by Peter Calvert 335

Walne, Peter (ed.): A Guide to Manuscript Sources for the History of Latin America and the Caribbean in the British Isles, by Charles C. Griffin

Winpenni, J. T.: Brazil, Manufactured Exports and Government Policy: Brazil's Experience since 1939, by David Carneiro Jr.

WYNIA, Gary W.: Politics and Planners, by David Browning 161 


\title{
QUANTITATIVE SOCIAL SCIENCE RESEARCH ON LATIN AMERICA
}

\author{
edited by Robert S. Byars and Joseph L. Love
}

In this guidebook to research on Latin America, six leading practitioners of quantitative approaches evaluate relevant studies and indicate critical areas for new research in their respective disciplines: Peter $\mathrm{H}$.

Smith (history), Robert C. Hunt (social anthropology), George Cowgill (archaeology), Howard L. Gauthier (geography), Clifford Kaufman (political science), and Alejandro Portes (sociology). An appendix describes sixteen data banks in the United States and Latin America and supplies information on the type of studies for which data were collected, the countries and time ranges covered, and the means of access. "Fills a considerable void in our knowledge of quantitative social science research on Latin America."-Orbis.

272 pages. $\$ 8.95$

\section{SINNERS AND HERETICS}

The Politics of Military Intervention in Latin America

\section{Mauricio Solauń and Michael A. Quinn}

The causes of coups d'etat in Latin America are explored in detailed investigations of thirty different coups and contemporary theories of political stability and breakdown. The authors contrast intraelite conflicts enacted by primitive radicals ("sinners") with interclass confrontation enacted by ideological radicals ("heretics"). Drawing from legal theory, they establish optimal requirements for political stability in a democratic context. "Latin American sociologists and economists will find interesting commentary in this thorough analysis." - Library Journal.

288 pages. $\$ 8.95$

\section{LATIN AMERICAN MODERNIZATION PROBLEMS}

\section{Case Studies in the Crises of Change}

edited by Robert $E$. Scott

Eight in-depth probes of specific problems, ranging from a Brazilian factory worker's political values through the legal maze of Colombia's land reform to a critique of nation-building efforts by military regimes in Latin America, show just how technology and its unintended side effects overburden the social, economic, and political structures.

Recommended by Library Journal.

373 pages. $\$ 12.50$ 


\title{
Brazil
}

The Land and the People

\section{Rollie E. Poppino}

This book concentrates on the social and economic development of Brazil from colonial times to the present. For the second edition, the bibliography, tables, and statistics have been updated. The last two chapters discuss the rapid changes that have taken place since the mid-1960s: the high economic growth rate, the government's growing concern with social issues, the systematic political repression. Second edition $£ 4.25$ paper covers $£ 1 \cdot 40$ OUP New York

\section{Os Lusiadas \\ Luís de Camões \\ Edited by Frank Pierce}

The great epic poem The Lusiads by the sixteenth-century Portuguese poet Luís de Camões appears here in the first English edition since 1946. The introduction provides a critical survey of the poet's life and works, considers the influence of the poem in Portugal and abroad, and attempts to explain its place in European history. $£ 1 \cdot 40$

\section{Buenos Aires}

\section{Plaza to Suburb 1870-1910}

\section{James R. Scobie}

This is a social and economic history of South America's largest city in the period of its most rapid growth. The book describes the development of the port of Buenos Aires, the establishment and expansion of rail links, the way the streetcar transformed the city, the conflict between city and Federal Government, It also deals with social structure, immigration patterns, and the changing nature of housing. £5.75 OUP New York

\section{To Hunt in the Morning}

\section{Janet Siskind}

This is an ethnographic study of the Sharanahua Indians of Peru. The author's contrasting of real behaviour and norms of behaviour is important both to anthropologists who study behaviour and to laymen interested in this subject. The book closes with a frank discussion of how the Indians are changing under the impact of the ever-encroaching Peruvian culture. Illustrated $£ 3 \cdot 15$ OUP New York

\section{Akwe-Shavante Society}

\section{David Maybury-Lewis}

\author{
Illustrated paper covers $£ 1 \cdot 40$ OUP New York
}




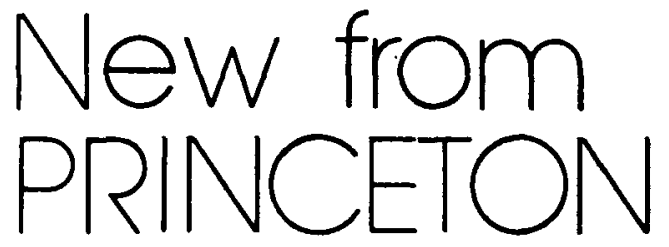

\section{THE UNITED STATES AND THE CARIBBEAN REPUBLICS, 1921-1933 \\ DANA GARDNER MUNRO}

Dana Gardner Munro discusses the shift in United States policy from that of active intervention to one of noninterference in the internal political affairs of the Caribbean states. In his analysis the author concentrates on several important issues-the failure to compel political reforms in Cuba from 1921 to 1923, the withdrawal of the occupations from the Dominican Republic and Haiti, the intervention in Nicaragua, the response to the Machado and Trujillo dic. tatorships, and the refusal to recognize revolutionary governments in Central America. $\$ 17.50$

\section{THE BRAZILIAN-AMERICAN ALLIANCE, 1937-1945 FRANK D. MCCANN, JR.}

Frank D. McCann uses previously inaccessible Brazilian archival material to discuss the events which brought about a close alliance between the United States and Brazil during the regime of Getulio Dornelles Vargas. The author's analysis of Brazil's decision to join the Allies affords a view of the diplomatic uses of economic and military aid and provides insights into the military's influence on foreign policy, and into the functioning of Vargas' Estado Novo. $\$ 18.50$

\section{LIBERAL AMERICA AND THE THIRD WORLD Political Development Ideas in Foreign Aid and Social Science} ROBERT A. PACKENHAM

"The author has no problem in showing that much of liberal rhetoric about economic development and political democracy in the period of effort and enthusiasm was egregiously optimistic or simply overblown. From this, as the natural counterpart, come some of the present disappointment and pessimism." -John Kenneth Galbraith, The New York Times Book Review \$15.00

\section{CONFLICT AND POLITICAL CHANGE IN VENEZUELA}

\section{DANIEL H. LEVINE}

To explain the transformation of Venezuela into one of the few effective democracies in Latin America, Daniel H. Levine analyzes the development of modern mass-based political parties, the changing structure and content of social and political conflict, and the emergence of common norms for political behavior. $\$ 13.00$

\section{Now in paparback}

THE MILITARY IN POLITICS

\section{Changing Patterns in Brazll}

\section{ALFRED STEPAN}

"A sound and objective study, indispensable for historians concerned with the evolution of the political process in Latin America and highly recommended for those dealing with military governments, past or present, in other areas of the world."-American Historical Review Cloth, \$12.50; Paper, \$3.45 


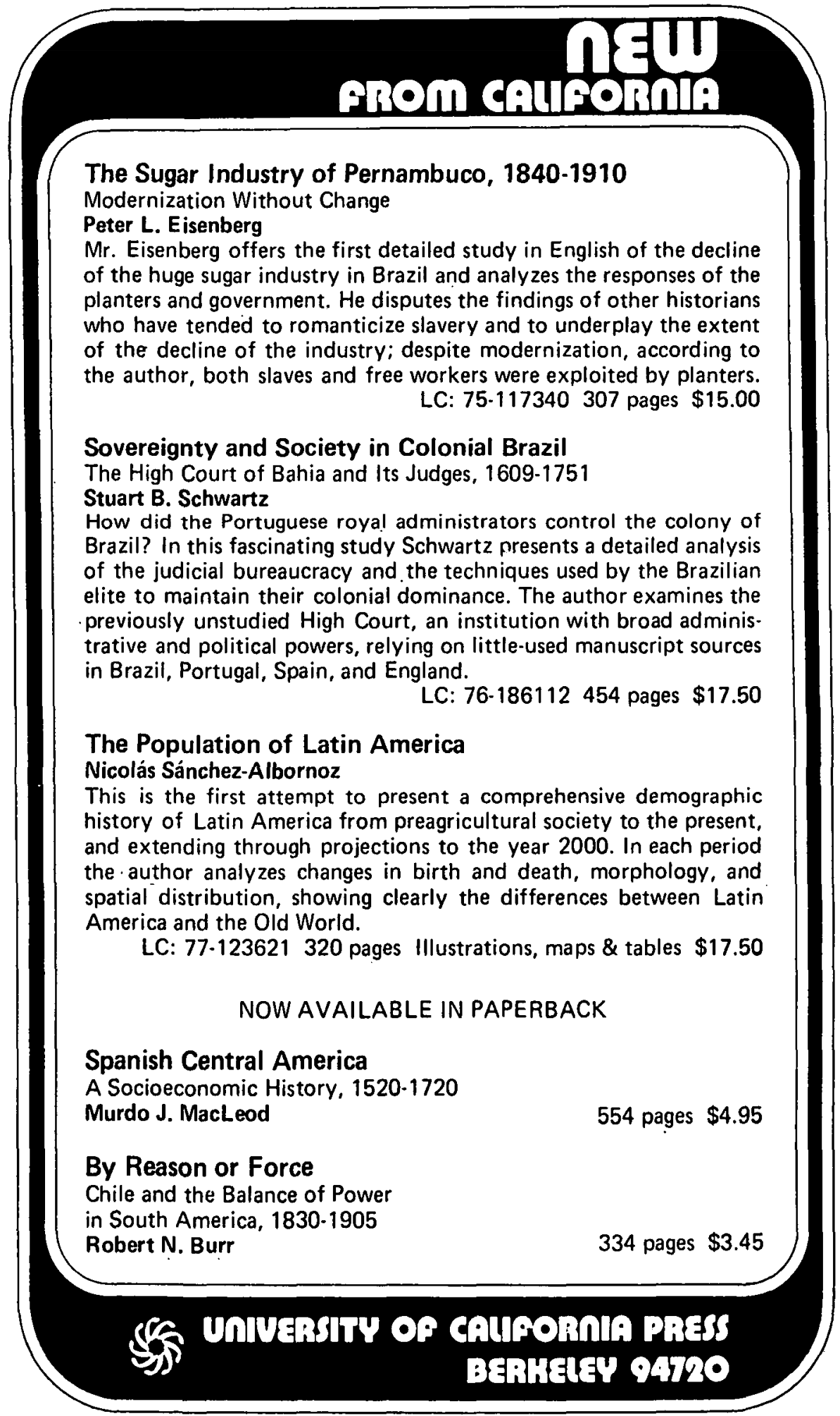




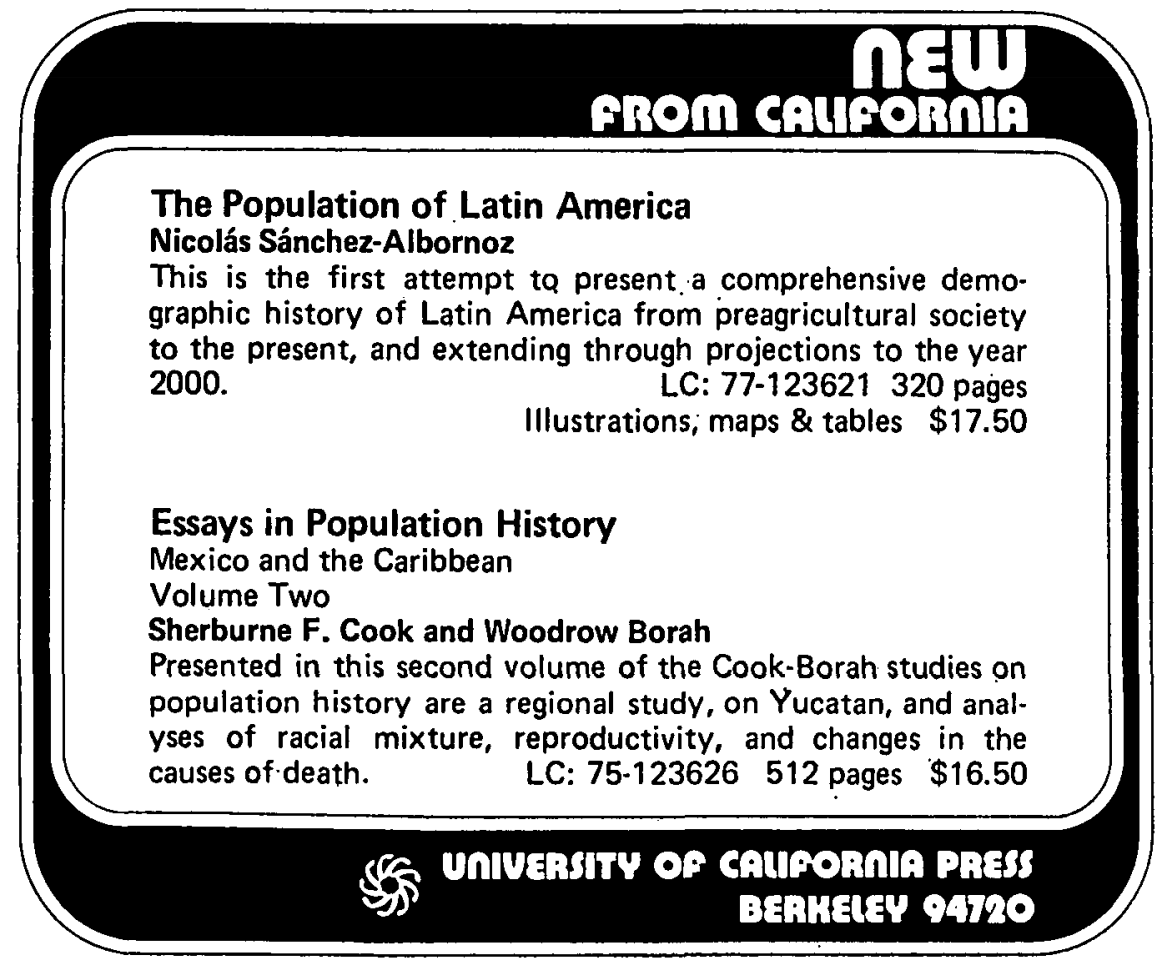

Vol. VI, No. 2

1974

\section{Cultures et développement}

Revue internationale des sciences du développement

SOMMAIRE

ARTICLES

Toyomasa FusÉ, Japan's Economic Cooperation in Southeast Asia. Its Scope, Prospects and Assessment.

F. RODEGEM, La fonction hyperphatique du langage.

Richard DALE, Refugees from South Africa to Botswana. The External Ramifications of Internal Security Policy.

Lion de SAINT-MoUlin, La répartition de la population du Zä̈re en 1970.

A. SteINHERR et J. GOUVERNEUR, Le nouveau secteur de "proprićté sociale" au Pérou.

Norman B. SCHwaRTZ, Milperos, Chicleros, and rituals of passage in El Petén, Guatemala.

\section{CHRONIQUE}

Jan VANSINA, Frobenius redivivus.

OUVRAGES ENVOYES A LA REDACTION.

BIBLIOGRAPHIE DES SCIENCES DU DEVELOPPEMENT.

\section{TARIFS D'ABONNEMENT}

4 numéros par volume. 1 volume par an. Belgique: 600 Frs. Etranger : 650 Frs belges. A payer par virement ou chèque bancaire à la Société Générale de Banque à Leuven (C.C.P. 9.82), pour le compte No. 230. 48119.27 de "CULTURES ET DEVELOPPEMENT".

A D R E S E

62, Tervuurse Vest, 3000 LEUVEN (Belgique) 


\title{
REVISTA DEL CENTRO DE ESTUDIOS EDUCATIVOS
}

\author{
VOLUMEN IV, No. 1 \\ ENERO-MARZO DE 1974
}

ARTICULOS

CARLOS MUNOOZ J., Expansión escolar, mercado de trabajo y distribución del ingreso en México (Un análisis longitudinal 1960-70).

GUILLERMO SANHUEZA, La educación y la oferta de mano de obra en Chile.

OARMEN GARCIA et al., Televisión y rendimiento escolar en Venezuela.

GONZALO CATAÑO, Desarrollo de la investigación sociológica sobre educación en Colombia.

INFORMES, NOTAS Y DOCUMENTOS

La cooperación externa en el desarrollo de la educación superior: puntos de vista latinoamericanos. Por Victor L. Urquidi.

Proyecto de educación extraescolar en Ecuador. Por David R. Evans y James Hoxeng.

Subdesarrollo y programación de la educación en una provincia del Brasil. Por Luiz Navarro de Britto.

ESTADISTICA

Educación extraescolar y alfabetización, enseñanza preescolar y primaria en México en 1972-1973. Por Isidoro del Camino y Jorge Muñoz B.

COMUNICACIONES

Sección abierta al diálogo o al debate sobre los puntos de vista publicados en la Revista.

RECENSIONES DE LIBROS

\section{PRECIOS DE SUSCRIPCION}

PARA MEXICO: $\$ 150$ m.n. ( $\$ 120$ para estudiantes y maestros).

PARA OTROS PAISES, correo ordinario: 12 dls.; correo aéreo: Centro y Sud América, USA y Canadá,' 15 dls.; otros paises, 20 dls.

Suscripción y collaboraciones a:

REVISTA DEL CENTRO DE ESTUDIOS EDUCATIVOS

Apdo. 27-321

México, D. F. MEXICO

\section{REVISTA DEL CENTRO DE ESTUDIOS EDUCATIVOS \\ VOLUMEN IV, No. 2 \\ ABRIL-JUNIO DE 1974}

\section{AR'TICULOS}

Estructura ocupacional de la industria y demanda de mano de obra especializada en Sao Paulo (Brasil)

José Pastore y Ana Ma. Bianchi.

Capacitación sindical y conciencia campesina.

Marcela Gajardo.

Investigación en televisión educativa

Regina Gibaja.

COMUNICACIONES

Televisión comercial y educación media (Relación causal o incidental?)

Mario L. Pacheco.

Respuesta a los comentarios del Lic. Pacheco

Ernesto Schiefelbein.

INFORMES, NOTAS Y DOCUMENTOS

Informe de actividades del Centro de Estudios Educativos, 1973

Bibliografia comentada sobre la educación en México, en las épocas prehispánica y colonial

Luz Elena Galvain Lafarga.

ESTADISTICA

La enseñanza media en México en 1972

Isidoro del Camino y Jorge Muñoz Batista.

RECENSIONES DE LIBROS

La Revista del Centro de Estudios Educativos aparece trimestralmente.

Precios de SusCripCion. En México, \$1 50 m.n. (estudiantes y maestros, \$120).

En ostros países, por correo ordinario, 12 dls.; por correo aéreo: Centro y Sud América, Canadá y USA, 15 dls.; otros países, 20 dls.

Para colaboraciones y suscripciones, dirigirse a :

REVISTA DEL CENTRO DE ESTUDIOS EDUCATIVOS Av. Revolución 1291, México 20, D. F. 


\section{Creating Efficient Industrial \\ Administration}

\section{By ARTHUR L. STINCHCOMBE}

With the Assistance of ZAHAVA BLUM and RENE MARDER

January 1974,220 pp., $\$ 9.50, £ 4.45$

Drawing upon studies of steel plant administrations in Chile, Argentina, and Venezuela, Professor Stinchcombe analyzes data on such things as the allocation of work time, attitudes toward careers, and attitudes toward political questions that apply to industrial relations. He then uses quantitative analysis to bring these data to bear on the theoretical questions posed by theorists like Max Weber, and concludes-in his typically fresh and laconic manner - that conditions of organizational structure are infinitely more important than cultural values or personal motivations.

CONTENTS:

Part I -INTRODUCTION: The Sociology of Administrative Rationality in Industry

Part $\|$-COGNITION AND BUREAUCRATIC STRUCTURE

Part III-THE MOTIVATION OF ECONOMIO ACTIVITY

Part IV-THE POLITICS OR ECONOMIC DEVELOPMENT APPENDIX ON METHOD

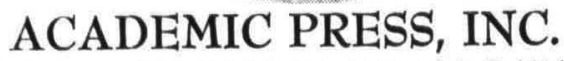

A Subsidiary of Harcourt Brace Jovanovich, Publishers

111 Fifth Avenue, New York, New York 10003

24-28 Oval Road, London NW1 7DX 


\section{NOTES FOR CONTRIBUTORS}

Journal of Latin American Studies is published twice a year under the academic sponsorship of the Centres or Institutes of Latin American Studies at the Universities of Cambridge, Glasgow, Liverpool, London and Oxford.

The scope of the journal is the study of Latin America from the standpoint of the social sciences, including anthropology, archaeology, economics, geography, history, international relations, politics, sociology, etc., though it is not concerned with linguistic or literary studies.

Editorial policy avoids commitment to any political viewpoint or ideology, but welcomes free discussion of such issues in the Latin American context, on the understanding that all responsibility for opinions expressed rests exclusively with the author concerned and not with either the journal or its editors.

Contributions are invited from all parts of the world. Articles should generally not be more than 8,000 words long, and two copies, typed with double-spacing, should be submitted. Diagrams and maps may be included by arrangement with the editors. The journal is published in English, but articles written in other languages will be considered, and arrangements made as required for translation into English. Contributors should keep one copy of the typescript for use in correcting proofs.

All contributions and editorial correspondence should be addressed to Journal of Latin American Studies, Institute of Latin American Studies, $3 \mathrm{I}$ Tavistock Square, London, WCrH ${ }_{9} \mathrm{HA}$.

Each contributor will receive, free of charge, 25 offprints of his article and a copy of the issue of the journal in which it appears.

\section{CONTRIBUTORS TO THIS ISSUE}

Dr B. T. F. Poole is Assistant Professor of Spanish at Mount Allison University.

Dr Louisa Hoberman is Assistant Professor of History at Wesleyan University, Connecticut.

Dr Christon I. Archer is Assistant Professor of History at the University of Calgary.

Dr Paul B. Goodwin, JR is Assistant Professor of History at the University of Connecticut.

Dr Mrron J. Frankman is Assistant Professor of Economics at McGill University.

Srmon Mrtchell is Lecturer in Sociology at the Institute of Latin American Studies, University of Glasgow.

Peter Flynn is Director of the Institute of Latin American Studies at the University of Glasgow. 


\section{Journal of}

\section{Latin American Studies}

Volume 6 Part 2 November 1974

\section{A R T I CLES}

B. T. F. Poole: Case Re-opened: An Enquiry into the 'Defection' of Fray Bernal Boyl and Mosén Pedro Margarit

193-210

Louisa Hoberman: Bureaucracy and Disaster: Mexico City and the Flood of 1629

Christon I. Archer: Pardos, Indians and the Army of New Spain: Inter-relationships and Conflicts, 1780-1810

Paul B. Goodwin, JR, The Politics of Rate-making: the Britishowned Railways and the Unión Cívica Radical, 192 I-1928

Myron J. Frankman: Sectoral Policy Preferences of the Peruvian Government, 1946-1968

Simon Mrtchell: The Influence of Kinship in the Social Organization of North East Brazilian Fishermen: A Contrast in Case-Studies

Peter Flynn: Brazil: Authoritarianism and Class Control (Review Article)

\section{REVIEWS by}

Peter Calvert, 335-336; F. Parkinson, 336-337; David J. Fox, 338-339; James D. Cochrane, 339-340; Warwick Bray, 340-34I; Sister Mary Noel Menezes, 34I-342; J. P. Dickenson, 343; J. T. Winpenny, 344-345; David Carneiro, Jr, 345-347; Christopher Abel, 347-349; Alan Gilbert, 349-350; Kenneth Duncan, 350-352; John Stuart MacDonald, 352-355; D. Winder, 355-357.

(C) Cambridge University Press 1974

CAMBRIDGE UNIVERSITY PRESS

Bentley House, 200 Euston Ruad, London NW 12 DB

American Branch : 32 East 57th Street, New York, N.Y. 10022

Single parts $£_{4.00}$ net in U.K. (U.S. $\$ 12.00$ in U.S.A. and Canada)

Subscription price £6.50 net in U.K. (U.S.\$19.50 in U.S.A. and Canada) for institutions; $£_{4.50}$ (U.S.\$13.50) for individuals

Printed in Great Britain by The Eastern Press Ltd., London and Reading 